\title{
A Raster Based Geospatial Model for Natural Gas Transmission Line Routing
}

\author{
V. Yildirim, T. Yomralioglu and R. Nisanci \\ Additional information is available at the end of the chapter
}

http://dx.doi.org/10.5772/45814

\section{Introduction}

The most important step in planning activities of Natural Gas Transmission Line (NGTL) is an applicable route selection [1]. Because obtaining the optimum route on a surface is a very complex process. Because many factors must be considered at the same time, and it is an important step for the NGTL projects. Defined route has influence on the project in every stage in economical, environmental, sociological and temporal way [2]. To reduce unfavorable effects as much as possible in terms of flora and fauna, and the environment and to complete the project at least cost base on the efficiency of the route. Determining the best route depends on examination, query and analysis of many complex data together [3]. Route determination requires spatial data from different organizations and state institutions, and it also needs to be carefully chosen, saved, queried and analyzed. Today, this type of analysis and a quick result are possible with Geographical Information System (GIS). GIS is an effective engineering tool for systematically organizing factors affecting route determination. When these factors are identified based on the length of the project, a GIS should be used to evaluate these factors simultaneously. Additionally the GIS based visualization technologies and cartographic abilities are generally adequate to determine the effective routes $[4,5,6,7,8]$.

Route problems, including route selection, route planning, finding the optimal route, corridor analysis and site selection, can be solved using network analysis based on GIS. GIS technologies have significantly improved recently. As one of the most important current information technologies, it is used as an effective tool in network analysis. Network analysis can be carried out on both vector-based data, such as roads, streams or pipelines, and raster-based data from non-defined space. Nevertheless, applications of network analysis for route determination of linear engineering structures must be carried out with raster-based data because they do not have a defined space $[9,10,11]$. Route determination 
with raster-based data is advantageous because it is simple to perform cost calculation, design, and modeling and to obtain Remote Sensing (RS) data directly in raster format $[12,13,14,15]$.

Raster data model is the most useful data format to carry out arithmetic operations among pixels of same coverage or different coverage on the same geographical location. Today, lots of GIS software extensively uses specific functions such as surface analysis, determination of the least cost route, forming arithmetic operations among the coverage, thanks to advantages provided by raster data format. In raster operations, surface crossing among pixels is more effective than crossing among lines on the vector based network analysis. Because obtaining the optimum route or the least cost route can be possible with the movement among the pixels on raster based continuous data, not on vector based finite line. Many researchers, realizing the importance of the taster approach in route determination process, have carried out various studies and have provided solutions to eliminate the deficiencies of this method continuing from past to present $[16,5]$.

Many factors in NGTL studies must be examined together. These factors exist in a complex and dispersed structure. Generally, decision makers randomly determine factors which they will use and effect rates of these factors to the route. However, required factors in determining route must be organized in a specific systematic manner in importance order. As a result of statistical examinations, required factors should be determined and the number of factors must be minimized as possible as. Besides these factors, the effect rates to the route need to be determined by using Multi Criteria Decision Making (MCDM) methods. In this sense, raster based routing model which will be generated should include the factor and determination process dynamically [17].

In route determination of NGTL, as not to be able to determine potential landslide areas, protected areas, flora/fauna areas, wetlands, rocky areas, soil types, other infrastructure lands, agricultural activity lands and may factors affecting the route in advance cause environmental and economic problems in these projects. Especially in Turkey, there are many present projects in which the pipelines, passing through the landslides, have been reconstructed; as coming across the breeding place of a specific type of animal, NGTL is waited for breeding time for days; pipelines as also coming across hard rocks or steep slope were reconstructed by taking back to avoid sharp turning and there is extra cost for crossing unnecessary streams and wetlands [18]. In other countries, besides these problems, there are projects which NGTL has been passing through fault lines [19], ore beds [20] and residential areas [21] causing the deaths of many people. Additionally, there are also projects that have been cancelled without completing the estimated operating time of the pipelines or have been repaired again with excessive maintenance costs because of not having determined the factors (groundwater causing corruption and abrasion) that affect the occupancy of NGTL [22].

\section{NGTL routing model}

Being carried out the process of NGTL route determination with GIS based models provides many advantages economically, environmentally and sociologically [23,24]. Like in all GIS 
applications, efficiency of results is proportional to the data quality. In determining route studies of NGTL projects, many data should be collected, stored and analyzed depending on the size of the field. Requiring location determination, the route determination problem might be basically perceived as a location problem. Because in these problems, every factor, affecting the route, corresponds to a location data set.

The deficiency of location data, used in studies including large areas that different corporations in Turkey require, has negatively influence on GIS studies which will be held on a regional scale. Maps used by many public corporations are 1:25.000 scaled topographic maps produced by General Command of Mapping (GCM). Corporations provide needed data (road, river, residential areas, natural sources, etc.) with these maps. However updating of these maps throughout the country requires a long time process. These map produced for defense purposes are not enough for the usage of different disciplines. The first stage of GIS based route determination method is to obtain the necessary location data/information by taking into account the factors affecting to the route [25]. In this process, the majority of the data that will be used as base is the location data (Figure 1).

\begin{tabular}{|l|l|}
\hline Land Cover & Other Linear Engineering Structures \\
\hline Rock Areas & Highway \\
\hline Forest Area & Railway \\
\hline Agriculture Area & Settlement \\
\hline Flora / Fauna & Residential Areas \\
\hline Recreation Area & Ownership \\
\hline National Park & Industrial Areas \\
\hline Protected Area & Oil pipeline \\
\hline Wetlands & Natural Gas Pipeline \\
\hline Geology & Power Transmission line \\
\hline Fault Lines & Spatial \\
\hline Lithology & Data \\
\hline Elevation & Irrigation/Drying Canals \\
\hline Ore Beds & Boundaries \\
\hline Soil & Hydrology \\
\hline Landslide & Streams \\
\hline & Lakes \\
\hline & Irrigation Canal \\
\hline & Underground Water sources \\
\hline & Source of drinking water \\
\hline & River basins \\
\hline
\end{tabular}

Figure 1. Spatial Dataset for NGTL routing

Spatial and non-spatial data required in determining NGTL routes are in large volume and vary very much. Requirement of studying effectively these data has revived raster based GIS methods in the recent years [26,27]. GIS is one of the most effective tools to analyzethe data in a whole. The data which will be used as input in NGTL route determination is needed at many stages (cost, operation, maintenance, time, efficiency of the line etc.) of pipeline project [28]. 
The first stage in raster based route planning model is defining the factors that affect NGTL route determination. Factors affecting the route determination of NGTL project vary in themselves. The factors affecting the determination is quiet different in crossing between the land and the sea. The effect ratios of these factors must be also identified. These rates called as factor weights are able to be determined in different ways. In this study, raster based route planning model has been generated by taking account of land crossing of NGTL in a dynamic structure in which necessary factors, weights of factors and related data layers can be studied as a whole (Figure 2).

\begin{tabular}{|l|}
\hline Accuracy Analysis \\
\hline Factors and Data \\
\hline NTGL ROUTING CONCEPTUAL MODEL \\
\hline Weights \\
\hline Determining of Weight Coefficients Based on Shareholders \\
\hline Ensuring of Weight Coefficients Based on Professionals \\
\hline Series of Spatial Analysis \\
\hline MCDM Analysis \\
\hline Raster Network Analysis \\
\hline Determining of Alternatives Routes \\
\hline Optimum Route \\
\hline Checking \\
\hline Factors \\
\hline Data Gathering \& Data Processing \\
\hline
\end{tabular}

Figure 2. NGTL routing conceptual model [17]

\section{Factors}

In raster based routing model, spatial and non-spatial data corresponding to factors affecting the route must be primarily obtained by paying attention to sufficient accuracy and precision. In Turkey context, many problems are experienced during the period from producing spatial data to sharing them [29]. Difficulties in reproduction of spatial data that are not probable, non- spatial data in a scattered structure and probable data without required quality are some of the most important reasons. Completing the process of data collection which is the most important part of the entire system in terms of time and cost, and data layers belonging to factor that will be used must be generated (Table 1).

In NGTL routing, factors, and weight of these factors vary depending on the precision of project's construction, execution and maintenance. For example, in an area in which intense landslides occur, landslide factor is amplified. Or identification of accurate obstacle is generated for flora-fauna factor while determining the route through the areas which are sensitive environmentally, such as tropical areas. In this context, factors affecting the route are generally classified in three main titles: environmental, economical and sociological factors (Table 2). 


\begin{tabular}{|c|c|c|c|c|c|c|c|c|c|c|c|c|c|c|}
\hline Buṭsso.j eune & & & & & & & & $\times$ & & & & & & \\
\hline 8u!̣ssox sәد.มnosax хәңе $M$ & $\times$ & & & & & & & & & & & & & \\
\hline 8uाssox еәле рәңэәғолd & & & & & & & & $\times$ & & $\times$ & & & & \\
\hline 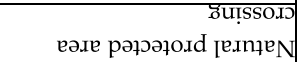 & & & & & & & & & & $\times$ & $\times$ & & & \\
\hline 8uṭsso.j еәле иоџ̣еәләәу & & & & & & & & & & & & $\times$ & & \\
\hline 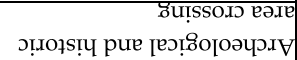 & & & & & & & & & & & & $\times$ & & \\
\hline 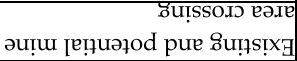 & & & $\times$ & & & & & & & & & & & \\
\hline 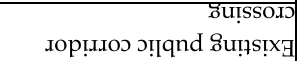 & $x$ & & & & & $>$ & $<$ & & & & & & $\times$ & $\times$ \\
\hline 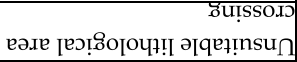 & & & $x$ & & & & & & & & & & & \\
\hline 8uṭsso.s ado[s łsadəə⿱一 & & $\times$ & & & & & & & & & & & & \\
\hline 8u!̣soxs Кем!!ex pue peoy & $\times$ & & & & & $>$ & 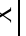 & & & & & & $\times$ & \\
\hline 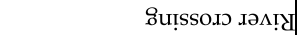 & $\times$ & & & & $\times$ & & & & & & & & & \\
\hline \&u!̣ssox วน! & & & $x$ & & & & & & & & & & & \\
\hline 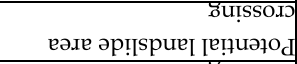 & $x$ & $\times$ & $x$ & & $>$ & $>$ & $<$ & & & & & & & \\
\hline 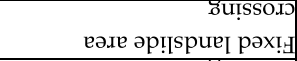 & $x$ & & $x$ & & & & & & & & & & & \\
\hline 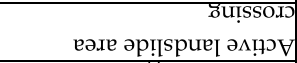 & & & & & & & & & & & & & & \\
\hline 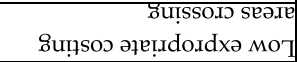 & & & & & & & & & & & & & & $\times$ \\
\hline 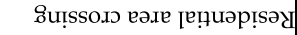 & $\times$ & & & & & & & & & & $\times$ & & & \\
\hline 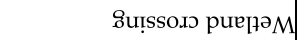 & $\times$ & & & & & & & & & & & & & \\
\hline 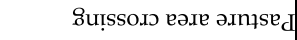 & $x$ & & & & & & & & & & & & & \\
\hline 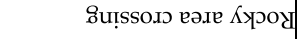 & $\times$ & & & & & & & & & & & & & \\
\hline 8uțsox еәле łsәлон & $\times$ & & & & & & & & & & & & & \\
\hline 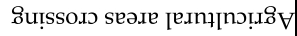 & $\times$ & & & $\times$ & & & & & & & & & & \\
\hline чұр!м лор!ฺлољ & \multicolumn{14}{|c|}{ 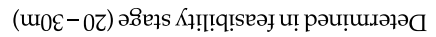 } \\
\hline 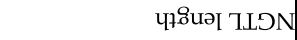 & \multicolumn{14}{|c|}{ 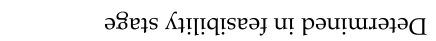 } \\
\hline uọ̣eł!̣u!̣ & 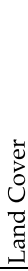 & 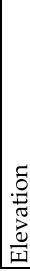 & 3 & $\begin{array}{l}\bar{O} \\
\mathcal{B}\end{array}$ & 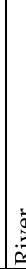 & & 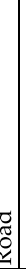 & 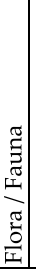 & 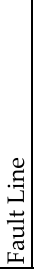 & 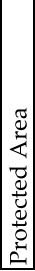 & 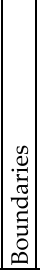 & 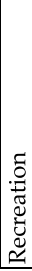 & $\begin{array}{l}\vec{\pi} \\
3 \\
\overrightarrow{3} \\
\tilde{\Xi}\end{array}$ & 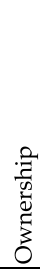 \\
\hline
\end{tabular}

Table 1. Limitations which affect NGTL route and relevant data layers 


\begin{tabular}{lccc}
\hline & Economical & Environmental & Sociological \\
\hline Land Cover & $\mathrm{X}$ & $\mathrm{X}$ & $\mathrm{X}$ \\
Elevation & $\mathrm{X}$ & & \\
\hline Geology & $\mathrm{X}$ & & $\mathrm{X}$ \\
Soil & $\mathrm{X}$ & & \\
\hline River & $\mathrm{X}$ & $\mathrm{X}$ & \\
Road & $\mathrm{X}$ & $\mathrm{X}$ & \\
\hline Railway & $\mathrm{X}$ & & \\
Flora / Fauna & & $\mathrm{X}$ & $\mathrm{X}$ \\
\hline Earthquake/Fault & $\mathrm{X}$ & & $\mathrm{X}$ \\
Protected Area & & $\mathrm{X}$ & $\mathrm{X}$ \\
\hline Boundaries & & & $\mathrm{X}$ \\
Recreation & & $\mathrm{X}$ & \\
\hline Ownership & $\mathrm{X}$ & &
\end{tabular}

Table 2. General classification of factors affecting NGTL Route

\section{Determination of factor weights}

In the process of route planning of pipelines, multiple qualitative and quantitative parameter should be evaluated in a whole and need to be decided basing on the results. When some of these parameters contradict with each other, the process of decision-making also called as the MCDM method is used to get more reliable results. In MCDM method, due to contradictory criteria, choosing the most appropriate alternative is very difficult for decision makers. After consideration of criteria, methods to remove these contradictions must be used to obtain the most accurate results [30].

The Analytic Hierarchy Process (AHP) is a method that is widely applied in decision theory; it is a paradoxical measurement method that includes measurable or abstract criteria. The Analytic Hierarchy Process (AHP), besides being a method which finds common practicing field in decision theory, is a measuring method which takes the controversial measurable and/or abstract criteria in to consideration. In AHP, if a decision is to made, the information and the experiences that are nearly in equal importance with the data are also taken into consideration. AHP is a tool which can be used in a wide scale from personal decisions to complicated management ones. The power of the theory is in both its simplicity and its applicability to varied conditions.

In AHP, specifying the scale is significant. In order to specify this scale, first, particular sets of number are taken and by using these numbers, it is decided how the modified priorities will be associated with each other. A scale consists of three elements: the mass of objects, the mass off numbers and determination of the mutual connections between the object and numbers.

In a standard scale a unit must be used to generate the values of the scale. Standard scale is used in measurement of objects or facts by using a unit developed to measure a specific 
feature. The numbers obtained from the scale function only in terms of human mind and do not have a value alone. The scale shown at the Table 3 is the basic scale of AHP.

\begin{tabular}{|c|c|c|}
\hline $\begin{array}{l}\text { Intensity of } \\
\text { importance }\end{array}$ & Definition & Explanation \\
\hline 1 & Equal importance & Two factors contribute equally to the objective \\
\hline 3 & $\begin{array}{l}\text { Somewhat more } \\
\text { important }\end{array}$ & $\begin{array}{c}\begin{array}{c}\text { Experience and judgment slightly favor one over the } \\
\text { other. }\end{array}\end{array}$ \\
\hline 5 & $\begin{array}{l}\text { Much more } \\
\text { important }\end{array}$ & $\begin{array}{l}\begin{array}{l}\text { Experience and judgment strongly favor one over the } \\
\text { other. }\end{array}\end{array}$ \\
\hline 7 & $\begin{array}{l}\text { Very much more } \\
\text { important }\end{array}$ & $\begin{array}{c}\text { Experience and judgment very strongly favor one } \\
\text { over the other. Its importance is demonstrated in } \\
\text { practice. }\end{array}$ \\
\hline 9 & $\begin{array}{l}\text { Absolutely more } \\
\text { important }\end{array}$ & $\begin{array}{l}\text { The evidence favoring one over the other is of the } \\
\text { highest possible validity. }\end{array}$ \\
\hline $2,4,6,8$ & $\begin{array}{l}\text { Intermediate } \\
\text { values }\end{array}$ & When compromise is needed. \\
\hline
\end{tabular}

Table 3. Pair wise scale in AHP

Similar items in every stage of hierarchy are compared for the next level criteria. The results taken from these comparisons are stated as numbers above. This scale shows the meaning of values from 1 to 9 . The values in the scale specify the density of connections of items. The matrix of pair wise comparison is generated as a result of pair wise comparison of all items. As the comparison of an item with itself is defined as a number, 1 ; the values of 1 are drawn out at diagonals of matrix. A number of $n(n-1) / 2$ comparison is made in an item matrix. The reason of it, the values of the 1 take place on the diagonal on account of comparing the items with themselves. In matrix, evaluation as the number of items of diagonals on the upper side is needed. This situation is derived from that evaluations under diagonal is opposite of the values upper side of the diagonal. Therefore the needed number of evaluation will be $\left\{\left(n^{*} n\right)-n\right\} / 2$.

\subsection{Pair wise matrix and factor weights}

Pair wise comparisons are one of the AHY components. The weight of the parameters used to determine the NGTL route are calculated by taking into consideration the pair wise comparisons of the parameters and the impact relative to each other affecting the route determination they make. Normally, the relative value of two parameters is based on the preference of the decision maker. In this study, Environmental Impact Assessments (EIAs) were prepared and examined for pipeline routing, existing applications, and scientific researchers to compare factors and sub-factors. Moreover, information was obtained from interviews with masters in BOTAS (Petroleum Pipeline Corporation), which is responsible for the pipelines in Turkey, and conversations with masters or experienced people in different corporations. Furthermore, current NGTL construction works were examined, and 
the relative degree of importance of the factors was determined at the end of the study [31,32].

The accuracy imparted by these weight values is studied by carrying out spatial analysis, questioning and cost evaluation [31,32]. Natural gas pipelines of which routes determined by using classical methods were optimized with this raster based route determination model and the values of weight were tested by comparing the results with original data on the land [31]. The results and statistical findings have shown that the weight values determined by this method are compatible with the original land data.

The number of factors defined for NGTL route planning is 10 in this study. In addition to these factors, absolute barriers were included in the process of routing.

First, determining relationships between basic factors affecting the route of NGTL is important. The matrix of pair wise comparisons between layers were generated to determine which layers are affected and to what extent they are affected (Table 4). Weights for each layer in the NGTL route were calculated. Moreover, consistency Ratios (CRs) related to the layers were calculated to determine the importance of these works.

\begin{tabular}{llllllllllll}
\hline & $\mathbf{A}$ & $\mathbf{B}$ & $\mathbf{C}$ & $\mathbf{D}$ & $\mathbf{E}$ & $\mathbf{F}$ & $\mathbf{G}$ & $\mathbf{H}$ & $\mathbf{I}$ & K & Weights \\
\hline $\mathbf{A}$ & 1 & 1 & 2 & 3 & 4 & 7 & 8 & 5 & 6 & 9 & 0.256 \\
$\mathbf{B}$ & 1 & 1 & 1 & 2 & 3 & 6 & 7 & 4 & 5 & 8 & 0.205 \\
$\mathbf{C}$ & $1 / 2$ & 1 & 1 & 1 & 2 & 5 & 6 & 3 & 4 & 7 & 0.156 \\
$\mathbf{D}$ & $1 / 3$ & $1 / 2$ & 1 & 1 & 1 & 4 & 5 & 2 & 3 & 6 & 0.116 \\
$\mathbf{E}$ & $1 / 4$ & $1 / 3$ & $1 / 2$ & 1 & 1 & 3 & 4 & 1 & 2 & 5 & 0.084 \\
$\mathbf{F}$ & $1 / 7$ & $1 / 6$ & $1 / 5$ & $1 / 4$ & $1 / 3$ & 1 & 1 & $1 / 2$ & 1 & 2 & 0.033 \\
$\mathbf{G}$ & $1 / 8$ & $1 / 7$ & $1 / 6$ & $1 / 5$ & $1 / 4$ & 1 & 1 & $1 / 3$ & $1 / 2$ & 1 & 0.025 \\
$\mathbf{H}$ & $1 / 5$ & $1 / 4$ & $1 / 3$ & $1 / 2$ & 1 & 2 & 3 & 1 & 1 & 4 & 0.061 \\
$\mathbf{I}$ & $1 / 6$ & $1 / 5$ & $1 / 4$ & $1 / 3$ & $1 / 2$ & 1 & 2 & 1 & 1 & 3 & 0.044 \\
K & $1 / 9$ & $1 / 8$ & $1 / 7$ & $1 / 6$ & $1 / 5$ & $1 / 2$ & 1 & $1 / 4$ & $1 / 3$ & 1 & 0.020 \\
\hline CR: $0,0136<0,10$ & & & & & & & &
\end{tabular}

A: Land Cover, B: Slope, C: Geology, D: Soil, E: Landslide, F: Stream, G: Road, H: Flora/Fauna, I: Protected Area, K: Recreation

Table 4. The matrix of pair-wise comparisons to determine the weights of factors that affect NGTL routing

The quality of the work is determined with the help of evaluation of obtained results in the AHP. Whether decisions support each other or whether they are meaningful can be determined. This work is carried out with CR in the AHP. Acceptable high point's value for $\mathrm{CR}$ is 0.10 . If $\mathrm{CR}$ is higher than 0.10 decision maker has to control his comparisons again. When weights related to data layers in NGTL route plan are examined (Table 1), factors such as land cover, slope, geology, soil and landslides affect the route more than the other factors. Sub-factor weights were calculated for each factor with the matrix of pair wise comparisons (Table 5). 
After factors were identified and relevant data layers were created, the weights of these factors and sub-criteria needed to be identified in the second stage. In this study, after criteria, taken into consideration in routing studies by using classical methods, the views of experienced and professional people, legal procedures and practices carried out in developed countries were examined as a whole, the process of determining the weight of factors was started. In this process, the most important processing step is interviews conducted in various institutions and organizations engaged in NGTL. As a result of determining the weights of factors supported with the interview results and literature studies, the weights of factors and subcriteria affecting NTGL route determination were identified by AHP.

In raster based route determination model, after needed factors were identified and formed properly, also some limitations need to be introduced. These limitations do not take any weight value and define a barrier. In route planning, the lands where the passing is strictly forbidden is defined as absolute barrier, and the lands in which passing is likely despite of its difficulty are also defined as relative barrier. Absolute barriers are determined in sense of the benefits expected from the entire project by users. In generated route planning model, residential zones, landslide areas, wetlands and fault lines were defined as absolute barrier and their weights were exemplified by defining as " $\infty$ ".

\begin{tabular}{|c|c|c|c|c|c|}
\hline Factors / Sub-Factors & Weights & CR & Factors / Sub-Factors & Weights & CR \\
\hline Land Cover & 0.263 & 0.0247 & Slope & 0.211 & 0.0108 \\
\hline Forest & 0.096 & & $<10^{\circ}$ & 0.031 & \\
\hline Cultivated Areas (Seasonal Agriculture) & 0.043 & & $10-20^{\circ}$ & 0.060 & \\
\hline Agricultural Areas & 0.063 & & $20-30^{\circ}$ & 0.081 & \\
\hline Wetland ${ }^{*}$ & 0.134 & $\infty$ & $30-40^{\circ}$ & 0.124 & \\
\hline Rocky Areas & 0.226 & & $40-50^{\circ}$ & 0.152 & \\
\hline Pasture Areas & 0.028 & & $50-60^{\circ}$ & 0.185 & \\
\hline Settlement Areas* & 0.411 & $\infty$ & $>60^{\circ}$ & 0.367 & \\
\hline Geology & 0.162 & 0.0443 & Stream & 0.040 & 0.0063 \\
\hline Acid-Intermediate Intrusives & 0.473 & & River & 0.444 & \\
\hline Basic-Ultrabasic Rocks & 0.288 & & Stream & 0.053 & \\
\hline Metamorphic Rocks & 0.149 & & Canal & 0.262 & \\
\hline Volcanic Rocks & 0.054 & & Brook & 0.153 & \\
\hline Sedimentary Rocks & 0.036 & & Creek & 0.089 & \\
\hline Protected Area & 0.049 & 0.0290 & Recreation & 0.023 & 0.0167 \\
\hline Level I & 0.407 & & Upland & 0.039 & \\
\hline Level II & 0.129 & & Tourism Center & 0.262 & \\
\hline Level III & 0.079 & & Historical Monument & 0.492 & \\
\hline Urban Protected Areas & 0.052 & & Picnic Areas & 0.069 & \\
\hline Historical Protected Areas & 0.333 & & Promenade Areas & 0.138 & \\
\hline Soil & 0.130 & 0.0278 & Road & 0.030 & 0.0238 \\
\hline I. Class soils - Excellent Agriculture & 0.269 & & Highway & 0.486 & \\
\hline II. Class soils & 0.251 & & Three Lane Road & 0.222 & \\
\hline III. Class soils & 0.193 & & Two Lane Road & 0.121 & \\
\hline IV. Class soils & 0.104 & & Stabilized Road (two lane) & 0.090 & \\
\hline V. Class soils & 0.081 & & Stabilized Road (one lane) & 0.044 & \\
\hline VI. Class soils & 0.045 & & Seasonal Road & 0.037 & \\
\hline VII. Class soils & 0.037 & & Landslide & 0.092 & 0.0334 \\
\hline VIII. Class soils - Non Agriculture & 0.020 & & Active Landslide Areas $^{*}$ & 0.633 & $\infty$ \\
\hline \multirow[t]{2}{*}{ Fault Line ${ }^{*}$} & \multirow[t]{2}{*}{$\infty$} & & Potential Landslide Areas & 0.260 & \\
\hline & & & Old Landslide Areas & 0.106 & \\
\hline
\end{tabular}

* absolute barrier

Table 5. Factor and Sub-factor weights affecting the NGTL route 


\section{Nabucco and Egypt-Turkey NGTL routing using the model}

A study has been carried out to show the applicability of raster based GIS model formed for studies of NGTL route determination. For this purpose, route determining studies have been carried out for Nabucco NGTL and Egypt-Turkey NGTL projects which have made concrete progress towards implementation and for which feasibility studies have been carried out. At first, the possibility of data was examined depending on factors affecting NGTL route. Problems especially in obtaining spatial data existed based on the size of the study area. Using spatial data, source and scale of the data are shown on Table 6. In evaluations that were executed, it was seen that when the most of the factors affecting route were taken into consideration, data that was missing (depending on weight values) did not change the route direction that was identified [31].

\begin{tabular}{lllll}
\hline Data & Data Type & Data Source & Date & Scale \\
\hline Elevation & Line & General Command of Mapping & 2008 & $1 / 100.000$ \\
Geology & Polygon & General Directorate of Mineral Research & 2008 & $1 / 500.000$ \\
Fault & Line & General Directorate of Mineral Research & 2008 & $1 / 500.000$ \\
River & Line & General Directorate of Mineral Research & 2008 & $1 / 100.000$ \\
Road & Line & General Directorate of Highway & 2008 & $1 / 100.000$ \\
Railway & Line & Turkish State Railways & 2008 & $1 / 100.000$ \\
Boundaries & Point & General Directorate of Rural Services & 2008 & $1 / 100.000$ \\
Lake & Polygon & General Command of Mapping & 2008 & $1 / 100.000$ \\
Forest & Polygon & General Command of Forestry & 2008 & $1 / 100.000$ \\
\hline
\end{tabular}

Table 6. The data used in route determination of the Nabucco NGTL Project.

In this study, the size of pixel was chosen to be $250 \mathrm{~m}$ based on the scale of data. Especially in these kinds of large-scale projects, routes determined by using raster based web analysis are often defined as a corridor and not a line depending on the size of the pixel. The route determined by using 20-30 meters- wideth large pixel size symbolized a corridor. Pipeline construction route of which width is 20-30 meters was able to be determined.

\subsection{Generating cost surface map}

After data layers were generated, NGTL cost surface map was formed by using the ArcGIS 9.3 software developed by ESRI Company and spatial analysis extension in this software. NGTL route determination query can be made by using generated cost surface map. It is easy to reach construction routes called as absolute route by using sensitive data in a corridor $250 \mathrm{~m}$ wide.

The weighted cost surface is generated by using pixel-based arithmetic processes on raster data layers formed for each surface separately. Weights needed for each layer are shown in Table 2. The value of pixels on this cost surface describes the total transition cost that belongs to the area on the surface (Figure 3).

$\mathrm{P}_{\mathrm{w}} \quad: \mathrm{P}_{\mathrm{i}}{ }^{*} \mathrm{~W}_{\mathrm{i}}$

$\mathrm{P}_{\mathrm{w}} \quad$ : weighted layer 
$P_{i} \quad: i^{\text {th }}$ data layer

$\mathrm{W}_{\mathrm{i}} \quad: \mathrm{i}^{\text {th }}$ data layer weight

In this implementation, the pixel size was chosen to be $250 \mathrm{~m}$. based on the scale of the data.

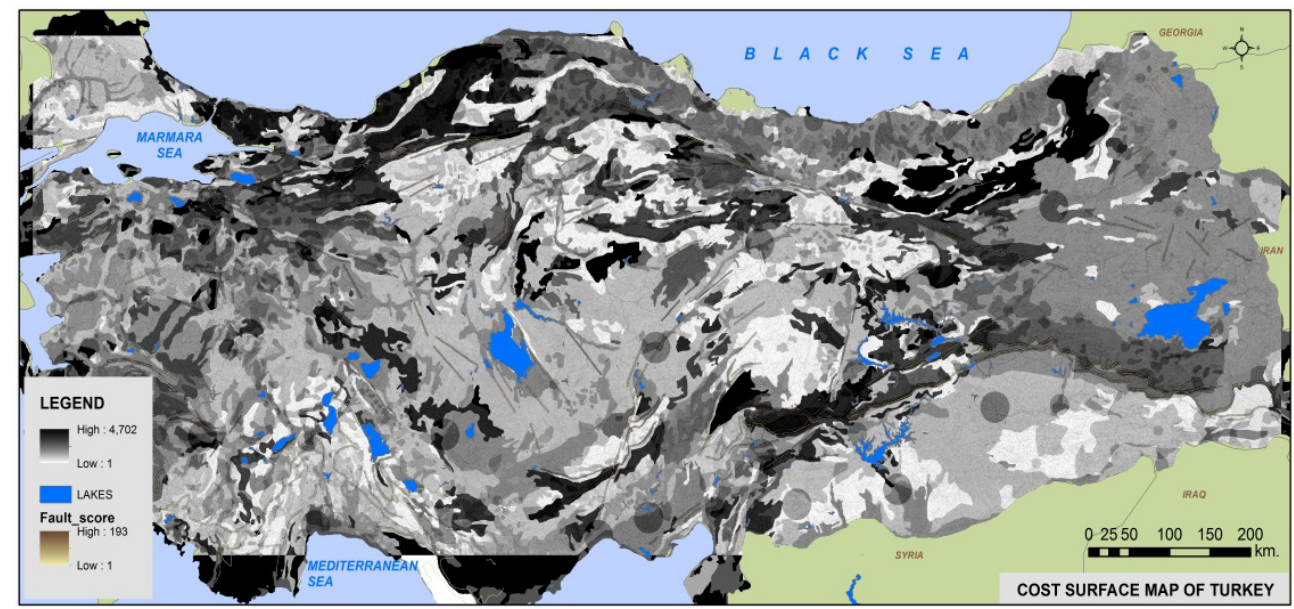

Figure 3. Cost surface map for the NGTL routing

\subsection{Nabucco NGTL routing}

The length of the pipeline recommended for Nabucco project has been defined as approximately $1584 \mathrm{~km}$. It crosses a total of 11 cities starting from Kars to Canakkale. In terms of the provincial administrative boundary, the longest crossing $332,8 \mathrm{~km}$ belongs to Kars city; the shortest crossing 71,9 km belongs to Kirikkale City (Figure 4). Although the route seems like a straight line, it makes deviations in significant distances in some crossing depending on the weight of the factor. For example, in Ankara provincial boundary, it has been seen that NGTL has deviated from line direction to not passing through the dense residential area. Route has made road crossing a total of 432 times including two highways.

The Nabucco Natural Gas Transmission Line Project is a new natural gas pipeline that will begin at the eastern border of Turkey and will connect the Caspian Region and the Middle East via Turkey, Bulgaria, Romania, and Hungary with Austria and further with Central and Western Europe gas markets. The pipeline will be approximately $3300 \mathrm{~km}$ long, stretching from the Georgian/Turkish and Iranian/Turkish borders to Baumgarten in Austria. Additional feeder pipelines are possible for Iraqi gas. Based on technical market studies, the pipeline has been designed to transport a maximum amount of $31 \mathrm{bcm}$ per year. The first aim of the project is to supply gas to the countries on the route, and then gas is to be transported to Western Europe according to the wishes of other countries in the following years. 


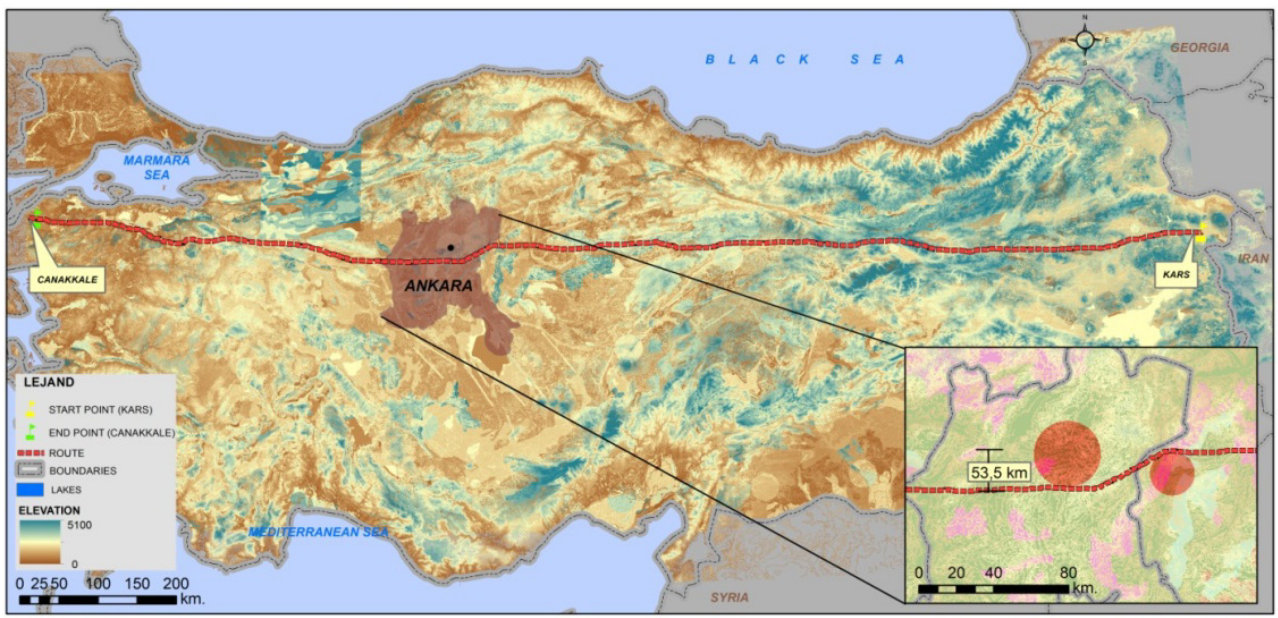

Figure 4. NGTL route on elevation data

\subsection{Determining Egypt-Turkey NGTL route}

The recommended length of the pipeline for the NGTL project of Egypt-Turkey is approximately stated $387 \mathrm{~km}$. It passes through a total of 4 cities starting from Kilis, a county of Gaziantep to Yusufeli, a county of Sivas. In terms of the provincial administrative boundary, the longest crossing 124,1 belongs to Sivas; the shortest crossing $49 \mathrm{~km}$ belongs to Gaziantep. The route crosses 28 streams including a river. Turkey-Egypt NGTL, plans to deliver gas to Europe market besides Turkey, passes over Israel and Syria. The route crossing is shown on figure 5 overlaid over cost surface crossing.

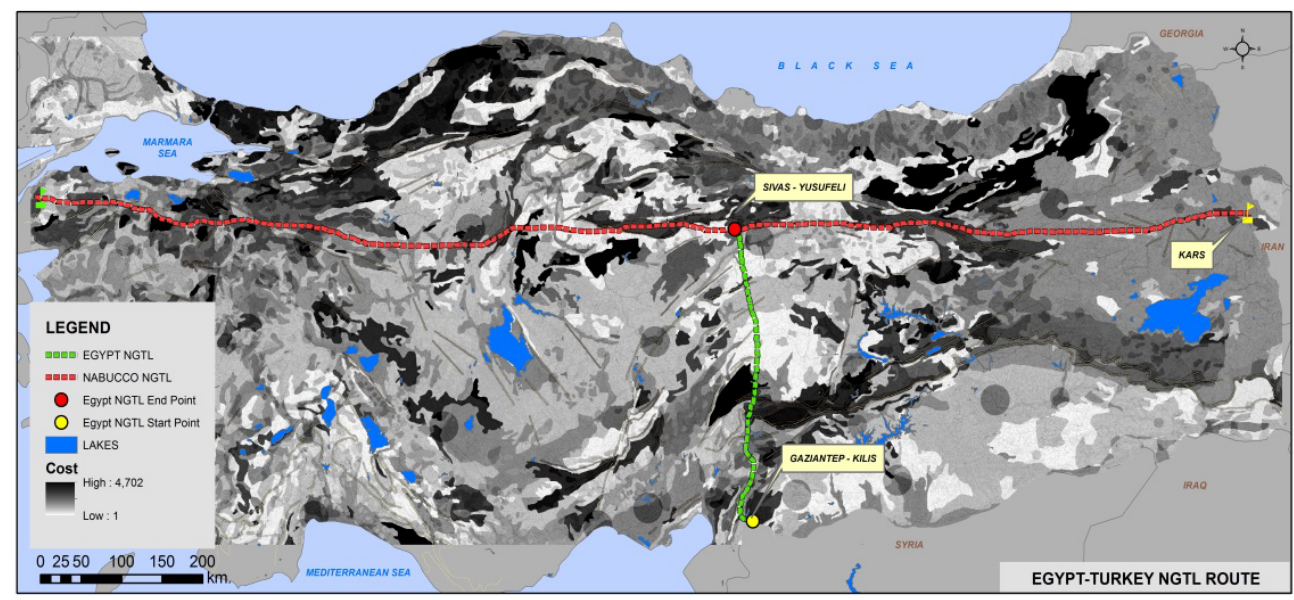

Figure 5. Egypt-Turkey NGTL route on cost surface 


\section{Results and findings}

Some analysis and questioning have been carried out for Nabucco NGTL and Egypt NGTL route to show the efficiency of the route determining model developed within this study. Nabucco NGTL route crosses 226 streams of which 195 are brooks, 3 are rivers, and 9 are streams. It has been seen that Nabucco NGTL has crossed North Anatolia Fault Line in the province border of Erzincan (Figure 6).

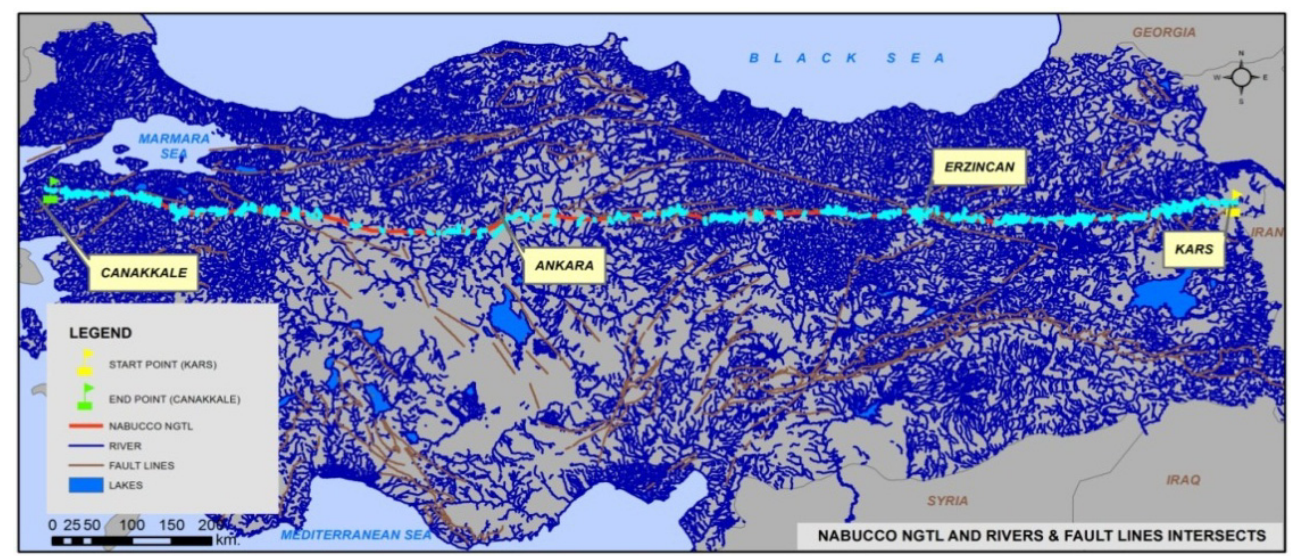

Figure 6. Crossing of rivers and fault lines of Nabucco NGTL

For Nabucco NGTL, the slope is at least $2 \%$, a maximum of $32 \%$ and an average of $5 \%$. While the minimum height of the pipeline is 52 meters, the height value can reach 3402 meters in some circumstances. The average height value of the pipeline is 1324 meters. Crossing of the pipeline through the areas of which slope value is more than $25 \%$, defined to be of high slope, is a total of 108 pixels, in other words, approximately $27 \mathrm{~km}$. Additionally, the length of the crossing on the high lands, $2500 \mathrm{~m}$ elevation is 580 pixel, i.e., approximately $145 \mathrm{~km}$.

The crossing of Nabucco NGTL on the lithology units is statistically evaluated. In this stage, rocks are placed in four categories. According to this evaluation, the route crosses soft areas over 3636 pixels, which is approximately $909 \mathrm{~km}$, and crosses 970 pixels of hard rock, which is approximately $242,5 \mathrm{~km}$. These results show that Nabucco NGTL route on the pattern does not pass through the areas that increase the cost due to geological reasons. 
It is seen that the proposed route for Nabucco NGTL has not passed through the center of dense residential areas like metropolitan, city, county, town. This result shows that accurate obstacle limitation for residential areas gives proper results. Egypt NGTL route crosses 28 streams of which 23 are brooks, 1 is a river and 4 are streams. Additionally, it crosses The South Anatolia Fault Line.

For Egypt-Turkey NGTL, the slope is at least $1 \%$, a maximum of $30 \%$ and an average of $4 \%$. While the minimum height of the pipeline is 350 meters, the height value can reach 2400 meters in some circumstances. The average height value of the pipeline is 1280 meters.

Also proposed route for Egypt Nabucco NGTL has not passed through the center of dense residential areas like metropolitan, city, county, town (Figure 7).

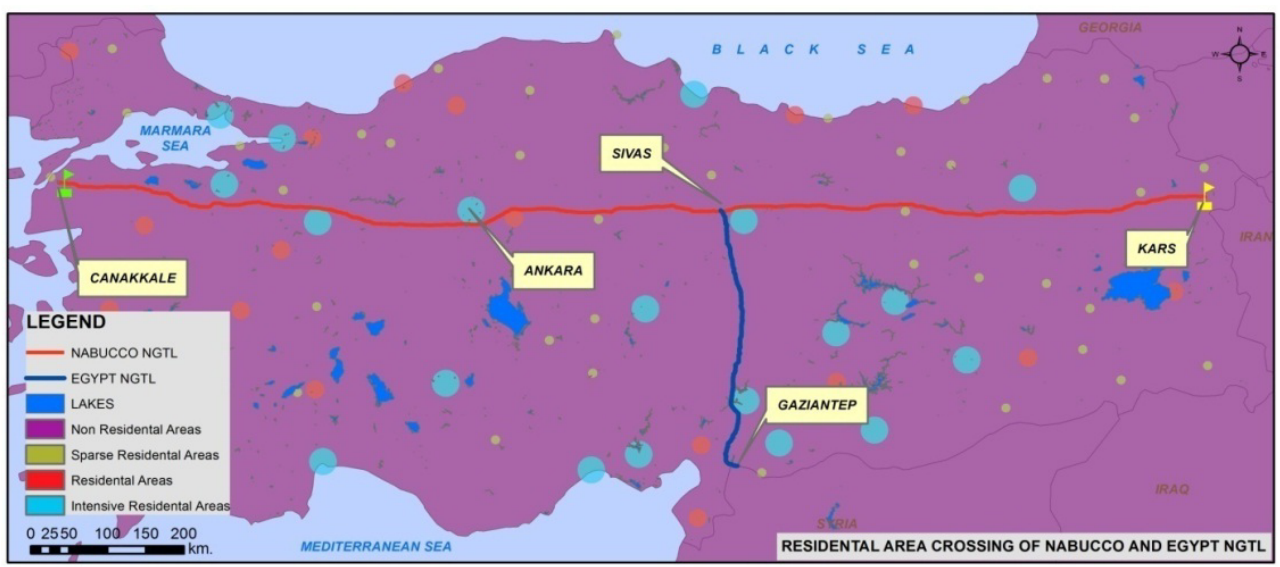

Figure 7. Residental Area Crossing of Nabucco and Egypt-Turkey NGTL

\section{Conclusions}

The NGTL route identification is complex and requires the analysis of large quantity of data and many parameters depending on the length of the project. GIS is one of the tools to perform this analysis effectively. GIS provides a large number of analytical functions that are capable of replacing manual and traditional methods of natural gas pipeline route planning. It is a powerful tool to integrate thematic layers in an automated environment to compute the shortest possible route with associated costs, which eventually reduce the cost and time of project execution and thus the operating expenses. The integration of GIS and the AHP provides a baseline for complex decision making in which the variant nature of criteria and stakeholders can be accounted for successfully. 
Raster-based data models and raster-based network analysis are necessary to determine the surface resistance and to model the NGTL route determination appropriately. One of the basic steps of route determination is to determine the factors that affect the route and their weights. In this stage, AHP presents effective solutions.

The accuracy of the results for this model is directly proportion of the quality of the information used. Especially in Turkey, spatial data it should be generalized with the use of a satellite image with the appropriate resolution. In this study, cost surfaces map that is 250x250 m pixels in size were generated based on available data and the data quality for Turkey. For any NGTL projects, the most appropriate corridor, which is 250 meters wide, can be determined easily with this map.

This model can easily be adapted to determine the necessary factors and calculate the weights for linear engineering structures, such as pipelines, waterlines, roads, channels, railways, and energy transfer lines.

This model is designed for Nabucco and Egypt-Turkey Pipelines Turkey crossing, but the model can be applied universally. In this model surface passage criteria factor weights can be changed and alternative routes can be created. Additionally, same factor weights can be used on same surface characteristics in developed and developing countries.

\section{Author details}

V. Yildirim

Karadeniz Technical University, Department of Geomatics Engineering, Trabzon, Turkey

T. Yomralioglu

Istanbul Technical University - Department of Geomatics Engineering, Maslak - Istanbul, Turkey

R. Nisanci

Karadeniz Technical University, Department of Geomatics Engineering, Trabzon, Turkey

\section{References}

[1] Huang Y, Zhang G, Wang J, Huang J, (2009) Design of Long Distance Pipeline Information Management Based on GIS, International Conference on Information Management, Innovation Management and Industrial Engineering, Available: http://ieeexplore.ieee.org/stamp/stamp.jsp?arnumber=05370526. Accessed Feb 12.

[2] Yang Z S, Jin J H, Yu P S, Chen C Y, Hao Q J, Zhai, Y Z (2010) Environmental hazards and contingency plans along the proposed Chinese-Russian Oil Pipeline route, NE China, Cold Regions Science and Technology. 64,3: 271-278.

[3] Ahmad N (2006) Determining Optimal Path Using GIS, Available: www.gisdevelopment.net. Accessed Feb 10.

[4] Yomralioglu T (2009) Cografi Bilgi Sistemleri Temel Kavramlar ve Uygulamalar. Fifth Edition, Istanbul, Secil Ofset. 479 p. 
[5] Rosado R I J, Fernandez J L A, Garcia G E, Zorzano S P (2005) Advanced Model for Expansion of Natural Gas Distribution Networks Based on Geographic Information Systems, Proceedings of the Fifth IASTED International Conference Power and Energy Systems, Available: http://www.actapress.com/Abstract.aspx?paperId=20783. Accessed Jan 24.

[6] Luettinger J, Clark T (2005) Geographic information system-based pipeline route selection process, Journal of Water Resources Planning and Managament, 131,3: 193200.

[7] Wang D, Wu M, Wang W, Wang F, (2009) The Determination of Optimal Rescue Route Based on Gas and Oil Pipeline GIS, Proceedings of the International Conference on Pipelines and Trenchless Technology, Available:

http://ascelibrary.org/proceedings/resource/2/ascecp/361/41073/60_1. Accessed Jan 25.

[8] Chand A, Gloven M, (2009) Using GIS to Support New Pipeline Construction and Material Procurement, Pipeline\&Gas Journal, Available:http://www.petroitg.com/CMS.pdf. Accessed Jan 25.

[9] Saha A K, Arora M K, Gupta R P, Virdi M L, Csaplovics E (2005) GIS-Based Route Planning in Landslide-Prone Areas, International Journal of Geographical Information Science, 19,10: 1149-1175.

[10] Yu C, Lee J, Stasiuk M J M (2003) Extensions to Least-Cost Path Algorithms for Roadway Planning, International Journal of Geographic Information Science, 17,4: 361376.

[11] Baban S M J, Yusof K W, Foster L D I, Ramlal B (2004) Modeling the Optimum Routes for Linking Potential Reservoir Sites to Demand Areas in Mountainous Tropical Islands, Surveying and Land Information Science, 64,3: 183-189.

[12] Cevik E, Topal T (2003) GIS-Based Landslide Susceptibility Mapping for a Problematic Segment of the Natural Gas Pipeline, Hendek (Turkey), Environmental Geology, 44: 949-962.

[13] Gutierrez Z G, Rubio O A (2004) Quantitive Assessment for Selecting the Route for a Gas Pipeline in Yucatan, Mexico, Human and Ecological Risk Assessment, 10,2: 451460.

[14] Rylsky I A, (2004) Optimization of Pipeline Routes Using GIS-Technologies, Vestnik Moskovskogo Universiteta, Geografiya, 5,4: 34-40.

[15] Malpica J A, Pedraza J (2004) Roads Extraction Through Texture From Aerial And HighResolution Satellite Images, The International Society for Optical Engineering, 4170: 358-366.

[16] Jafari J, Danehkar A, Khorasani N (2010) Application of Raster Images ,n Computing Environmental Risk Assessment (ERA) of Pipelines, World Applied Sciences Journal, 9,1: 91-100. 
[17] Yildirim V (2009) Development of a Raster Based Dynamic Model with Geographical Information System for the Determination of Natural Gas Transmission Pipelines, PhD thesis, Karadeniz Technical University, Trabzon, Turkey.

[18] Orhan A H, Yılmazer I, (2006) Alignment Selection Criteria for Pipelines Essential, Pipeline \& Gas Journal, 233:5, 43-44.

[19] Cluff S L, Page A R, Slemmons B D, Crouse B C (2003) Seismic Hazard Exposure for the Trans-Alaska Pipeline, 6th U.S. Conference and Workshop on Lifeline Earthquake Engineering, California, USA.

[20] Dey P K, Gupta S S (2001) Feasibility Analysis of Cross-Country Petroleum Pipeline Projects: A Quantiative Approach, Project Management Institute, Project Management Journal, 32:4, 50-58.

[21] Rowland A, (2005) GIS route selection analysis for Oil and Gas exploration using MultiCriteria Decision Analysis- Case Study of the Oil and Gas Producing area of the Niger Delta in Nigeria, MSc Thesis, University of Greenwich, London.

[22] Dey P K (2001) Integrated approach to Project feasibility analysis, Impact Assessement and Project Appraisal, 19:3, 235-245.

[23] Anavberokhai I O (2008) Introducing GIS and Multi-Criteria analysis in road pah planning process in Nigeria, MsC Thesis, University of Gavle, Department of Technology and Built Environment.

[24] Berry K J, King D M, Lopez C A (2004) Web-Based Application for Identifying and Evaluating Alternative Pipeline Routes and corridors, Available: www.innovativegis.com/basis/present/gita. Accessed Jan 14.

[25] Yomralioglu T, Reis S, Nisanci R (2002) GPS ile Hareket Halindeki Araçlardan Elde Edilen Gerçek Zamanlı Verilerin Orta Ölçekli CBS Çalışmalarında Kullanılabilirliği, Selçuk Üniversitesi Jeodezi ve Fotogrametri Mühendisliği Öğretiminde 30. Yıl Sempozyumu, Selçuk Üniversitesi, Konya, 107-115.

[26] Vincent C T, Yong H (2002) Assessment of Airborne Lidar and Imaging Technology for Pipeline and Safety Applications, Pecora 15/Land Satellite Information IV/ISPRS Commission I/FIEOS Conference Proceedings, Canada.

[27] Hall S, Nelson A, Meehan D, Mukherjee J (2005) Disseminating Critical Pipeline Infrastructure Data With GIS, Esri User Conference, USA.

[28] Hausamann D, Zirnig W, Schreier G, Strobl P (2005) Monitoring of Gas Pipelines - A Civil UAV Application, Aircraft Engineering and Aerospace Technology: An International Journal, 77:5, 352-360.

[29] Reis S (2003) Çevresel Planlamalara Altlık Bir Coğrafi Bilgi Sistemi Tasarımı ve Uygulaması: Trabzon İl Bilgi Sistemi (TİBİS) Modeli, Doktora Tezi, KTÜ Fen Bilimleri Enstitüsü, Trabzon.

[30] Yalcin A (2005) Ardeşen (Rize) Yöresinin Heyelan Duyarlılı̆̆ı Açısından İrdelenmesi, Doktora Tezi, KTÜ Fen Bilimleri Enstitüsü, Trabzon. 
[31] Yildirim V, Nisanci R, Yomralioglu T, Uzun B (2008) Raster-based GIS data guide economic pipeline construction, Oil \& Gas Journal, 106:13, 62-68.

[32] Yildirim V, Yomralioglu T (2007) GIS Based Pipeline Route Selection by ArcGIS, ESRI Users Group Conference, Accessed:

http://proceedings.esri.com/library/userconf/proc07/papers/papers/pap_2015.pdf USA. Available Jan10. 